\title{
ガスクロマトグラフィーと醸造への応用
}

\author{
(2)
}

\section{3. 酻造への忍用}

\section{3-1 序 論}

醇造物の香気成分の検索はこのものが微量で揮発性で あるため, 従来の方法では困難な場合が多く, 重要な問 題でありながらほとんど研究されていなかった。一方, ガスクロマトグラフィーはこれらの分離定量に偉大な力 を持つのであるから，最近数年の間にこの方面で急速な 発展をとげつつあるのは当然といえる。現在までは醇造 物やその原料などに含まれる揮発成分の種類やその量を 調べ，その香気との関係を求めた研究が多い。香気成分 の5ちアルコール類についての研究が最もさかんで, 新 らしい定量法が考案され，これを利用して䁔造工程を通 して成分の行方を追求したり, 製造工程を管理する手段 に用いる試みも見られる。

醇造物を試料とする場合, これが多量の水を含んでい ることが大きな問題となる。通常の分離操作で目的とす る揮発性化合物を水から定量的に分離することは非常に 難かしく, 一方通常の固定相液体では水のピークははな はだしく尾を引く（テーリング）することが多く, クロ マトグラムの作成に著しい妨げとなる。

そこで醸造物のガスクロマトグラフィーでは含水試料 でもさしつかえないような, たとえば水の保持時間がほ かの成分のそれよりも大きいカラムを選ぶことなどが重 要な問題となる。又イオン化検出器は水を検出しない ので, これを酒類分析に用いようとする研究24) も見られ る。

醸造物に含まれる香気成分は沸点が低いものが多く, これらの分離, 濃縮には主として蒸溜法が用いられ, 溜 液を脱水剂で処理する方法がとられているが，溶媒抽出 法を用いた研究例も多い。

これらの点について研究例をあげて参考に供したい。

\section{3-2 アルコール, エステルの定性及び定量法}

酸酵生産物中のアルコールについては古くから注目さ れ，多くの研究があるが，ガスクロマトグラフィーによ る定量もこれを対象としたものが多い。

* 国税庁醸造試験所

\section{吉 沢 淑}

平25)はカーボワックス 400 を固定相液体とする内径 4 $\mathrm{mm}$, 長さ $1 \mathrm{~m}$ の銅カラムを用い, アセトンを内部標準 物質としてメタノールを定量する方法を報告している。 アセトン $0.05 \%$ を含む $0.10,0.075,0.050,0.025$ $\%$ のメタール溶液を $12.5 \mu l$ ずつカラムに注入し, カ ラム温度 $45^{\circ} \mathrm{C}$, 流速 $55 \mathrm{ml} /$ 分で水素ガスを通じ, 測定

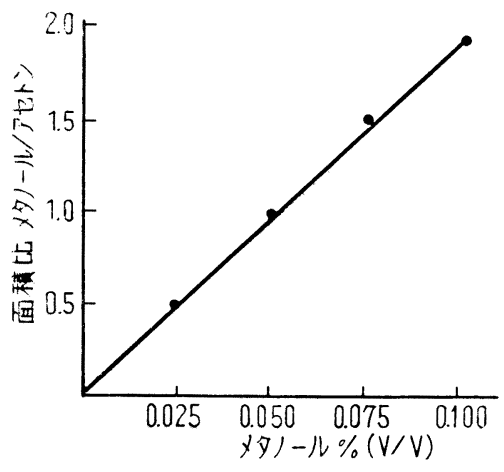

第 2 図 メタノールの検量線

を行なった。画かれたアセトン,メタノール両ピークの 半值巾に高さを乗じて面積を計算し，第 2 図に示すよう に両ピークの面積比とメタノール量との検量線を作成し た。

一方試料として白ブドウ酒 1 , 赤ブドウ酒 3 , ブラン デー 1, リンゴ酒 1 点のそれぞれ $100 \mathrm{ml}$ に少量の酸性

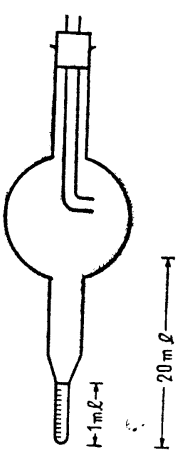

第3図フーゼ ル油定量用蒸 留フラスコ 炭酸ナトリウムを加え蒸溜し, 約 $2 / 3$ 量を溜出し，これにアセトンを 0.05 $\%$ になるように加え， $0.1 \mathrm{ml}$ をカ ムに注入してクロマトグラムのピーク 面積の比から検量線を用いて試料中の メタノール含量を定量している。

R. J. Bonthilet と W. Lowrey 26$)$ は フーゼル油中のn-プロパノール, イソ ブタノール, イソアミルアルコール

（活性アミルアルコールとの混合物） の定量法を考案しこれより計算された フーゼル油の量と, 従来の比色による 定量法とを比較している。 
第 3 困に示すような蒸溜フラスコに試料としてブラン デー $20 \mathrm{ml}$ を入れ, 沸石を加えて $95^{\circ} \mathrm{C}$ の湯浴中で残液 がフラスコ底部の $1 \mathrm{~m} l$ の画線以下になるまで蒸溜し， 冷却後残液にエタノールを加えて $1 \mathrm{ml}$ とし，その $15 \mu l$ をカラムに注入した。130C に保ったFlexol No.70001 カラムに水素ガスを流し, 得られたクロマトグラムの上 記アルコールのピークをプラニメーターを用いて測定し. 予め純アルコールの一定量を注入して作成した検量線か ら各構成アルコールの量を求めた。検量線の一例は第 4 因示すようである。

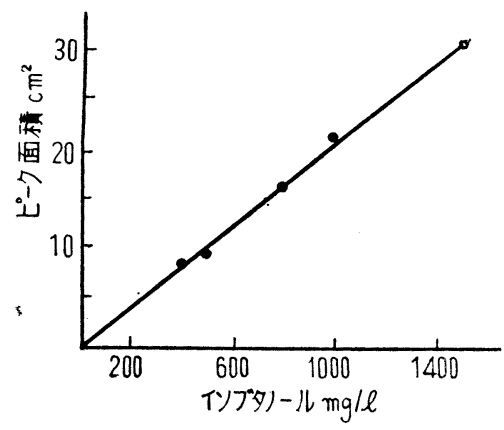

第 4 図イソブタノールの検量線

一方検体をパラジメチルアミノベンッアルデヒドー濃 硫酸試薬と反応させて生じた色を比色する従来の比色法 でフーゼル油量を測定し，ガスクロマトグラフィーでの 3アルコールの量を加えた值と比較した。しかし比色法 では $n$-プロパノールは測定されず，両法の間に一定の 関係を見いだすことはできなかった。ガスクロマトグラ フィーによる定量法は再現性も高く, 上り正確で, 構成 アルコールを直接別々に定量出来るなどで優れていると 述べている。

上林等 ${ }^{27)}$ はフーゼル油中に含まれるアルコールとエス テルについて多数のカラムを用いて定性法を検討し，ア ルコールの定量法を検討した。

アルコールについてはテトラエチレングリコールジメ チルエーテル, ポリエチレングリコール 1500, シリコ ン油 DC200なと 7 種の固定相液体のカラムを用いて水 を含めたメタノールからアミルアルコールまでの分離条 件を検討し，n-ブタノールに対する各アルコールの相対 保持容量を求めた。一例は第 5 図に示すようである。

又第 5 図に示すよ5にこれらのアルコールの同族体内 で，その炭素数または沸点と保持量容量の対数との間に 直線関係が成り立つことを認めた。

定量についてはテトラエチレングリコールジメチルエ 一テルカラムを用いて, n-ブタノールを内部標準物質と して, 水, エタノール, $n$-プロパノール, イソブタノー ル, イソアミルアルコール（活性アミルアルコールとの

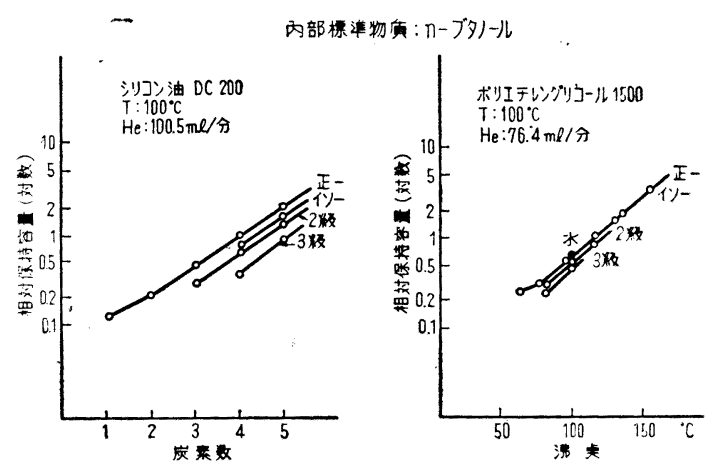

第 5 図アルコールの炭素数, 沸点と相対保持容量との 関係

混合物）対 $n$-ブタノールの面積比と重量比との検量線 を作成している。

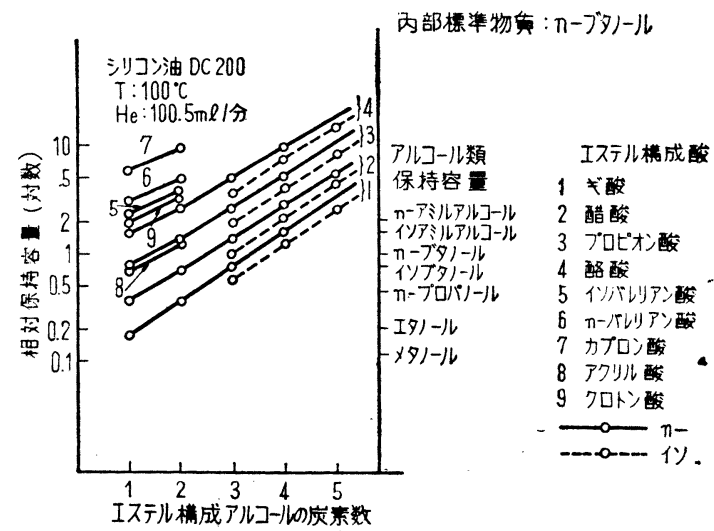

第 6 図 エステルの炭素数と相対保持容量との関係

ギ酸, 醋酸, プロピオン酸とアミルアルコールまでの エステル類の分離については, シリコン油 DC 200, ジ ベンジルェーテルなど 6 種類のカラムを用いてこれらエ ステルの $n$ ーブタノールに対する相対保持容量を求め, アルコールと同様に同族体内でその炭素数または沸点と 保持容量の対数との間に直線関係が成り立つことを認め た。一例は第 6 図に示すようである。これらのカラムを 用いることによりアルコールとエステルの分離定量が出 来る。

一方種々のカラムを用いてアルコール蒸溜により得ら れるフーゼル油のガスクロマトグラフィーを行ない, 微 量成分としてメタノール，n-ブタノール，n-アミルア ルコール, $n$-ヘキサノール, 醋酸エチル, 醋酸イソアミ ル, アセトアルデヒド, イソブチルアルデヒド, キ酸エ チルを検出した。

通常のフーゼル油中のアルコール以外の成分は 0.02 〜 $0.2 \%$ で, アルコールのガスクロマトグラフィーには 定量誤差 $1 \%$ 以下で問題は無い。

又アルコール蒸溜中の各段階に拈ける $n$-プロパノー 
ルの動きをカーボワックス 1500 のカラムを用いて追求 してその結果から蒸溜法について検討を行なっている。 $3-3$

3-3-1 ホップ揮発成分の分析

䤑造原料の揮発成分とその製品の香味との閣係につい てはホップがよく研究されている。

F.C. Rigby そ J.L. Bethune ${ }^{28)}$ は自製のガスクロマ トグラフを用いてホップ油を分析しな。

16 種類の乾燥ホップを試料とし，その $1 \mathrm{~kg}$ ずつを 4 時間水蒸気蒸溜し, 溜液の油分を集めてホップ油区分と した。ダウコーニング高真空シリコングリース $30 \%$ を $70 \%$ の七ライトと混合し, 内径 $6 \mathrm{~mm}$ 長さ $2.5 \mathrm{~m}$ のパ イレックスカラムにつめ, 温度 $185^{\circ} \mathrm{C}$, 流速 $27 \mathrm{ml} /$ 分で 水素ガスを流し, 試料 $0.02 \sim 0.15 \mathrm{ml}$ を注入し, 得られ たクロマトグラム上の各ピークの保持容量を推定物質の ピークのそれと比較して同定した。定量法は各ピークの 面積比がそのまま各成分の量比に等しいとして計算した。 クロマトグラムの一例は第 7 図泟すよ5であるが,

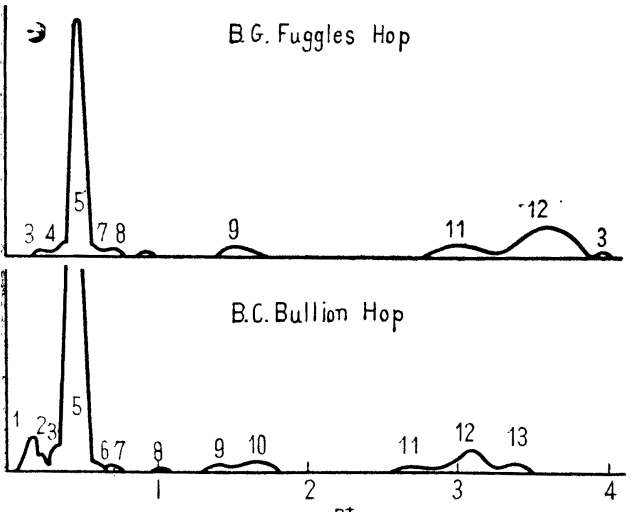

時

第 7 図 ホップ油のクロマトグラム
ロッパ産のホップは一般にミルセンが少なくフムレンが 多いが，アメリカ産のホップはその反対であった。

又向流抽出により分離された $\alpha$-酸区分とシリカゲル 液体クロマトグラフィーにより得られた含酸素区分につ いてガスクロマトグラフィーを行ない，その組成につい て検討している。

F.L.Rigby, E. Sihto, A.Bars ${ }^{29)}$ はホップの $\alpha$-酸区 分のガスクロマトグラフィーによる迅速定量法を考案し た。

彼等は G. A. Howard, A. R. Tatchell ${ }^{30)}$ の方法を改 良し， $\alpha$-酸の鉛塩を閉管中で $400^{\circ} \mathrm{C}$ に加熱し，ピロリ シスにより生じた脂肪酸を蒝溜により集め, 中和後石油 エーテルで中性区分を除きイソプロピルアルュールのエ ステルとして石油エーテルに移して試料とし，その $5 \mu 1$

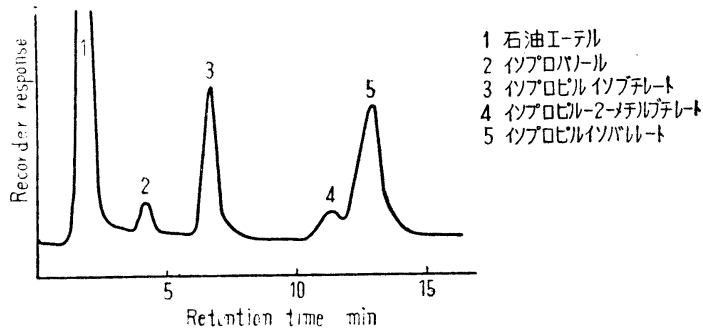

第 8 図 ホップ $\alpha$-酸区分から得られたイソプロピルエ ステルのガスクロマトグラム

をカラムに注入した。カラムは $2.5 \mathrm{~m}$ の Ucon カラム を $50^{\circ} \mathrm{C}$ に保ち, $40 \mathrm{ml} /$ 分でヘリウムを通じて分離を行 なった。クロマトグラムは第 8 図に示すよ5である。得 られたイソプロピルイソブチレート，イソプロピルイソ ハンレート，イソプロピル 2 メチルブチレートに対㐫す るピーク面積から各々の物質の量比を求め, これをその まま $\alpha$-酸区分中のコフムロン, フムロン, アドフムロ ンの量比とする。

第 2 表 ホップ油区分の組成

14 のピークが認められた。定 量の結果は第 2 表に示すようで ある。

第 2 表のピーク番号 $5,9,11$, 2, 13 の成分は全試料に認めら れ，全体の約 95\%を占める。 その保持容量とクロマトプレー ト法により，5. ミルセン，9.メ チルノニルケトン, 11. ペータ カリオフイレン, 12.フムレン, 13. ガンマカリオフイレンと同 定された。このうちミルセンと フムレンは最も多く含まれ, 油 分の $70 \sim 80 \%$ を占める。ヨー
Sonoma

Australian Hybrid 115/3/1 Idaho

\section{B. C. Bullion Oregon Seeded B. C. Hallertau Bavarian Hallertau Canadian Pride Steiermark \\ B. C. Kent \\ B.C. Bramlings \\ B. C. Fuggles \\ Tettnang \\ Yakima Seedless \\ B.C.Clusters \\ Backa}

\begin{tabular}{|c|c|c|c|c|c|c|c|c|c|c|c|c|c|c|}
\hline \multirow{2}{*}{$\begin{array}{c}\text { ホップ中 } \\
\text { の 油分 } \\
\%\end{array}$} & & & & & 小 & \% & $7^{\circ}$ & 油 & 成 & 分 & & & & \\
\hline & 1 & 2 & 3 & 4 & 5 & 6 & 7 & 8 & 9 & 10 & 11 & 12 & 13 & 14 \\
\hline 1.3 & 2 & 1 & 1 & 1 & 75 & 1 & 1 & & 2 & 1 & 6 & 11 & 2 & \\
\hline 0.8 & & & 1 & 1 & 51 & & 2 & & 5 & & 11 & 19 & 11 & \\
\hline 0.5 & & & & & 36 & & 2 & & 6 & & 11 & 42 & 3 & \\
\hline 0.7 & & & & & 24 & & 1 & & 6 & & 12 & 50 & 6 & \\
\hline 0.4 & & & 1 & & 41 & 1 & 2 & & 9 & & 7 & 38 & 1 & \\
\hline 0.6 & & & & & 34 & & 1 & & 5 & & 15 & 40 & 5 & \\
\hline 0.8 & 2 & 1 & 1 & & 43 & & 2 & & 5 & & 9 & 35 & 2 & \\
\hline 0.8 & 2 & & 1 & & 45 & & 2 & & 4 & & 10 & 37 & 1 & \\
\hline 0.8 & & & 1 & 1 & 42 & & 2 & 1 & 7 & & 12 & 31 & 3 & \\
\hline 0.5 & & & & & 26 & 4 & & 1 & 7 & & 17 & 37 & 8 & \\
\hline 0.6 & & & 1 & 1 & 49 & 3 & 1 & 2 & 8 & & 8 & 20 & 6 & \\
\hline 0.5 & & & 2 & 1 & 37 & $\underbrace{2}$ & 2 & 2 & 5 & & 7 & 35 & 7 & \\
\hline 0.6 & & 5 & & & 23 & & & 1 & 5 & 3 & 10 & 45 & 4 & \\
\hline 0.2 & & & & & 8 & & 2 & & 11 & & 15 & 46 & 13 & 5 \\
\hline 0.7 & & & & & 32 & 6 & 5 & 3 & 13 & & 8 & 6 & 14 & \\
\hline 0.2 & & & & & 50 & 2 & 5 & 1 & 9 & & & 5 & 16 & 3 \\
\hline
\end{tabular}


一方同一の試料について向流抽出法によりその組成を 求め, 上記の結果と比較検討している。

\section{3-3-2 ビール揮発成分の分析}

酒類のガスクロマトグラフィーでは上述の上らに試料 から出来るだけ水を除くか，水を含んでもさしつか充な いカラムや検出器を選ぶことが必要である。A.P. van der Kloot ${ }^{31)}$ 等はグリセロールを $20: 100$ の割合で耐火 煉瓦に混合したものを固定相として $75^{\circ} \mathrm{C}$ に保ち、ヘリ ウムを通じたクロマトグラフィーで水の影響をほとんど 無くすことが出来るのを示し, この方法で 29 種類のビ 一ルの揮発成分を分析した。 $100 \mathrm{~m} l$ のビールを蒸溜して 溜液 $5 \mathrm{ml}$ をとり，脱水することなくそのまま $0.05 \mathrm{ml}$ を注入し, 推定物質と試料とを混合して注入したクロマ トグラムと比較して同定した。さらに試料のビール各 $300 \mathrm{~m} l$ を一定の方法で蒸溜し， 4 区分の溜液各 $2.8 \mathrm{ml}$ を無水塩化マグネシウムで脱水し，その $0.05 \mathrm{~m} l$ をカラ ムに注入, 微量成分の検出を行なった。醋酸エチル，ア セトン, 醋酸アミル, エタノール, 活性アミルアルコー ル, イソアミルアルコールの順に保持時間が大きく, メ タノール, プロパノール, ブタノール, 水などはエタノ ールのピークと重なり,はっきり分離出来ない。結果は

第3表 ビール揮発成分の組成

\begin{tabular}{|c|c|c|c|c|c|}
\hline \multirow{2}{*}{\multicolumn{3}{|c|}{ 揮発 成 分 }} & \multicolumn{3}{|c|}{ ビール $1 l$ 中の $\mathrm{mg}$} \\
\hline & & & 最大値 & 最 小值 & 平均值 \\
\hline 醋 & 酸 & $\triangle チ ル$ & 27.4 & 14.5 & 21.4 \\
\hline & 女 & r V & 1.3 & 0.2 & 0.44 \\
\hline 醋 & 酸 & $ア ミ ル$ & 4.0 & 1.4 & 2.6 \\
\hline \multirow{2}{*}{\multicolumn{3}{|c|}{ 活性アミルアルコール }} & 32 & 14 & 19.5 \\
\hline & & & 71 & 13 & 57.7 \\
\hline
\end{tabular}

第 3 表に示すようである。これら化合物の量とビールの 香気との間にはっきりした関倸が認められなかったが, 高級エステルとアミルアルコール含量と “harsher”ま たは “heavier”といわれる香りの間にある関係が成り 立つようであった。

V.S. Bavisotto, L. A. Roch ${ }^{32}$ は van der Kloot ら の方法によりビール製造の各工程における微量揮発成分 の行方を追求し，酸酵中各成分は定まった時期に現われ 特定の比率で增加する。ビールを瓶詰すると 5 カ月間に
エステルとアミルアルコールは減少するが，アセトンは 一定であることなどを明らかにした。

F.V.Harold ${ }^{33,34)}$ 等はビール揮発成分をエーテル抽出 法を用いて集め, 固定相液体にアピエゾン $\mathrm{M}$, ジグリセ ロール，ベンジルジフェニールを用いてこれを分離固定 した。n-プロパノール, イソプロパノール, メタノール 2 級ブタノール，イソブタノール，n-ブタノール，イソ アミルアルコール，2級ブチルアセテート，醋酸イソブ チル, 醋酸イソアミル, 醋酸エチルの添か一群のピーク を認めているが同定していない。ホップに由来するもの としてカリオフィレン, フムレン, ファーネセン, メチ ルノニルケトン, イソカリオフイレンが認められた。

J. R. Hudson, R. Stevens ${ }^{35)}$ は $4 l$ のビールを蒸溜し て溜液 $1 l$ をとり, エーテル・イソペンタン $(1: 1)$ を溶 媒として揮発成分を抽出し，n-アミルアルコールを内部 標準物質として, 固定相液体に $25 \%$ のジノニルフタレ ートと 33\% のアーミンSD を用いたカラムと $23 \%$ の グリセロールを固定相液体に用いて分離同定を行なって いる。

F.Zientera， T.L.Owades ${ }^{36)}$ はカーボワックス 1500 を固定相液体とするカラムによりアメリカと他国産のビ 一ルの揮発成分の比較をし，アセトアルデヒド, 醋酸エ チル，醋酸アミルを見いだしているが，ビールの香気と の関倸は認められなかった。

\section{3-3-3 蒸溜酒そのほかの酒類の分析}

蒸溜酒は製法上酘酵生産物のうち揮発性物質だけを含 むのでガスクロマトグラフィーで扱い易い。

フーゼル油は高級アルコールを主体とする一群の揮発 性物質をい5, 蒸溜酒には約 $0.1 \%$ 含まれ, その香味に 大きく影響寸るとして古くからその量や組成が研究され ている。

著者 ${ }^{37}$ はウイスキー,ブランデー, カルバドス, ラム, しょうちゅうのフーゼル油を分離し，そのアルコール組 成を求めた。

各試料 $200 \sim 700 \mathrm{~m} l$ を溜液のアルコール分が $80 \%$ 以 上になるまでくり返して蒸溜し，得られた溜液を精溜し 塔頂の温度が $78 \sim 100^{\circ} \mathrm{C}$ の間に溜出した約 $5 \mathrm{ml}$ の溜液

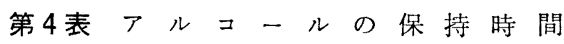

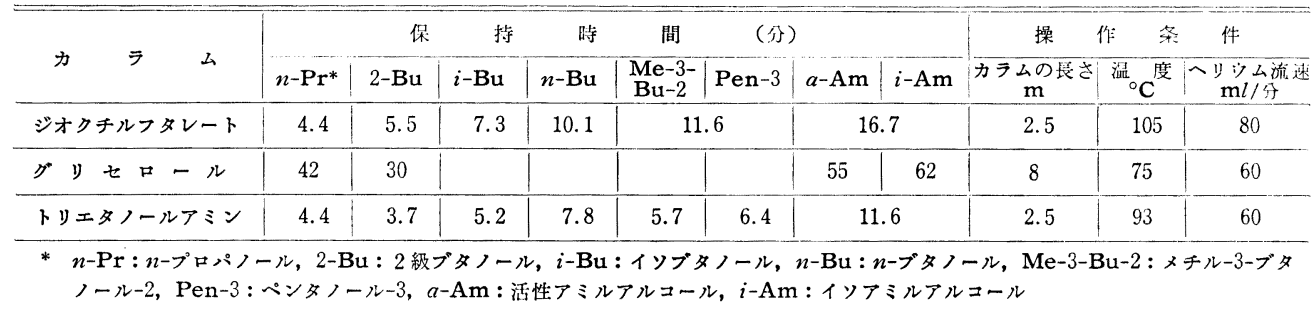


をフーゼル油区分とした。このものを無水硫酸ナトリウ ムで脱水，カラムに注入した。

フーゼル油にはアルコール以外にェステル，アルデヒ ドなどを含をので，試料をケン化，酸性西硫酸ナトリウ ム処理をしたものを注入して処理前のクロマトグラムと 比較したが，前述のようにこれらの量は試料の $1 \%$ 以内 で,これらを除かなくてもアルコールの定量にはさし支 えない。

使用カラム呐径 $4 \mathrm{~mm}$ の銅慗パイプに，固定相とし てC-22 ヒジオクチルフタレート $30 \%$, トリエタノール アミン $30 \%$ ，グリセロール 30\% の割合で叙付した 3 本 で，キャリヤーガスにヘリウムを用いた。使用条件と分 離されたアルコールの保持時間は第 4 表に示すようであ る。メタノール, エタノール, $n$ ープロパノール, イソプ ロパノール，n-ブタノール，イソブタノール， 2 級ブタ ノール， 3 級ブタノール，n-アミルアルコール，イソア ミルアルコール, 活性アミルアルコール, ペンタノール -3, メチル-3-ブタノール-2, n-ヘキシルアルコールが 分離される。

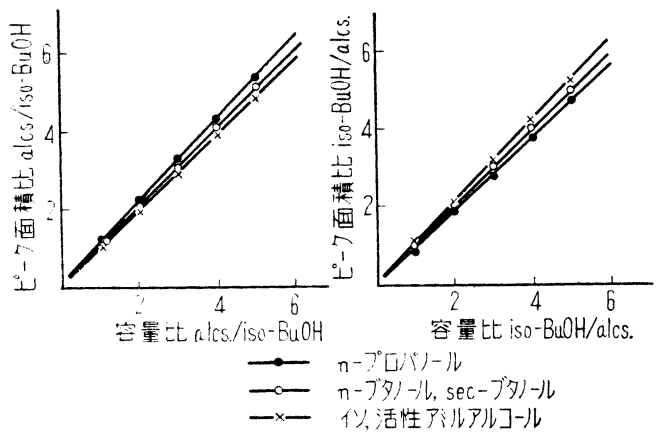

第 9 図フルコール検量線
ピークと他のピークとの面積比を求め, 予め作成した検 量線（第 9 図）によりイソブタノールと他のアルコール の容量比を求めた。

イソアミルアルコールと活性アミルアルコールはこの カラムでは分離されず，その総和で表わされるので，グ リセロールカラムで分離された両者のピークの面積比に 応じてその総和の值を分けた。

すべての試料にプロパノール, 活性アミルアルコール イソアミルアルコール, イソブタノールが認められた。

各酒類のフーゼル油構成アルコールとその組成は第 5 表に示すようである。第 10 図はクロマトグラムの数例 を示している。

蒸溜酒のフーゼル油にもっとも多く含まれる高級アル コールはイソアミルアルコールでフーゼル油の $32 \sim 64 \%$ を占め, ついでイソブタノール 6〜32\%, 活性アミルア ルコール 13〜24\%，n-プロパノール 5〜20\% の順に少 なくなるが二，三の例外が見られる。

一般に穀類より製した酒類ではイソアミルアルコール が少なく，逆に n-プロパノールが多い。ウイスキーは イソブタノールが多い。又多くのフーゼル油に微量の nーブタノールの存在が認められた。

特異な組成はカルバドスのそれであって，n-プロパ ールと 2 級ブタノールがほぼ同量ずつ全体の $50 \%$ を占 め，イソブタノールはわずか $6 \%$ しかない。微量な成分 としてnーブタノールとペンタノールー3 が認められた。 J. Baraud, L. Genevois ${ }^{38)}$ はシリコン/セライト (30: 70) を固定相とする長さ $4 \mathrm{~m}$ のカラムを $80^{\circ} \mathrm{C}$ 保ち, $0.9 l /$ 時で窒素ガスを流してブドウ酒, 糖蜜, ビートの 醴酵液のフーゼル油の高級アルコールを分析した。結果 は第 11 図に示すようであるが，ブドウ酒からはェタノ

定性法は試料成分のピーク の保持時間を標準アルコール のそれと比較し,さらに推定 物質と試料の混合液のクロマ トグラムから相当するアルコ ールを同定した。

定量法はジオクチルフタレ ートカラムを用いた試料のク ロマトグラムのイソブタノー ルのピークの大きさが余り変 らず,一方イソブタノールの 注入量が多少違ってもイソブ タノールと他のアルコールの 面積比と容量比との間の関倸 は变らないことを確かめたの で, 試料中のイソブタノール
第 5 表 蒸溜酒フーゼル油の高級アルコール

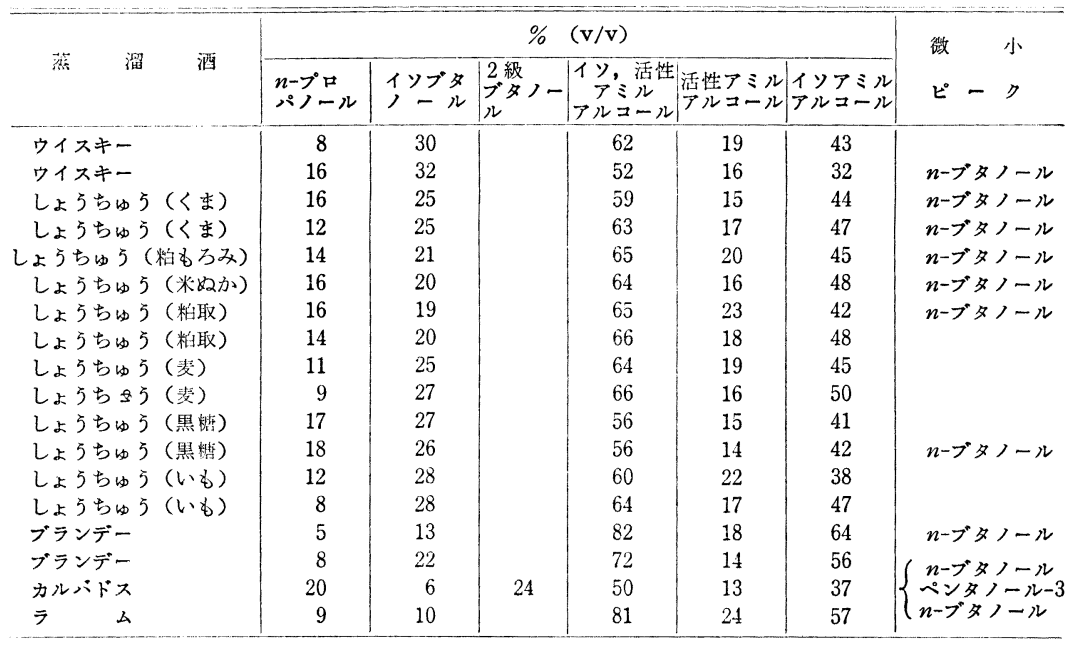


$(280)$
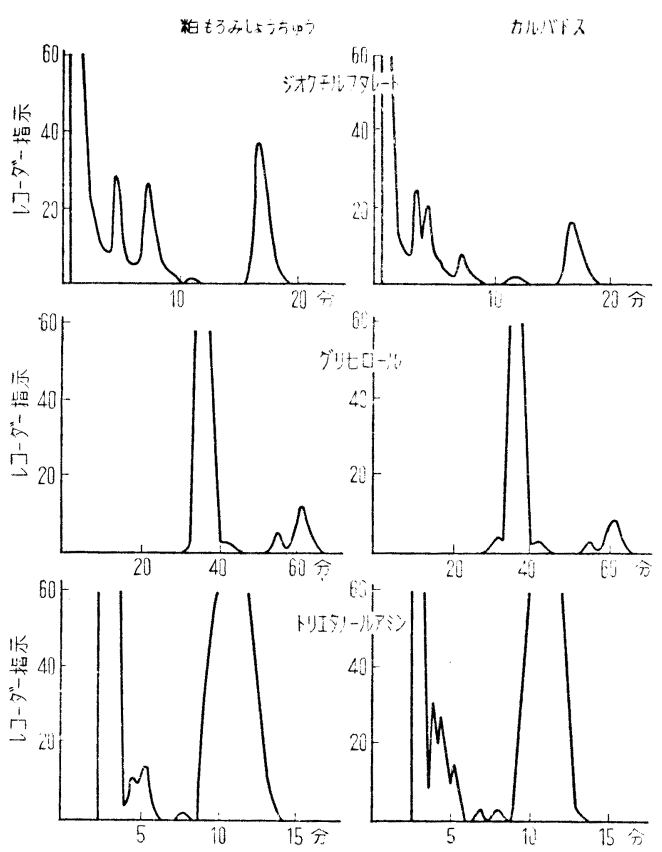

第 10 図蒸留酒フーゼル油のガスクロマトグラム

ル，イソプロパノール，n-プロパノール， 2 級ブタノ ール, イソブタノール, メチル-3-ブタノール-2, イソ アミルアルコールと活性アミルアルコールの混合物, $n$ ヘキシルアルコールが同定された。糖蜜のものはブドウ 酒のそれに比らべて 2 級ブタノールを含まずイソブタノ ールも少量であった。ビートのフーゼル油からはメチル -3-ブタノール-2の代りにペンタノールー3を見出した。 これらは赤外分光器, ラマン分光器をもらいて同定して いる。

そのほか A.Foussin ${ }^{39)}$ はカーボワックス 1500, トリ エタノールアミン, ジグリセロールの 3 つのカラムを用 いてコニャック, ウイスキー, ブドウ酒の揮発成分を分
析し, L.Fleischman, A. Daghetta ${ }^{4()}$ はトリクレジル フォスヘート/C-22 (25:75) を固定相とし, ビール, ブドウ酒を分析している。 R. Mecke, M. de Vries' ${ }^{41)}$ はペンタノール：エーテル 2 の溶媒を用いてフーゼル油 を抽出してガスクロマトグラフィーの試料としている。

A.D.Webb, R.E.Kepner'22) 1, 4-ブタンジオール, エリスリトール，グリセロール，ソルビトールなどを組 み合わせた 13 の固定相について高級アルニールの分離 能を検討している。

その他多数の報告があるが，ガスクロマトグラフィー は寸ばらしい速さで発展しつつあり，その輝かしい未来 を予想することはほとんど不可能に近いほどである。

これをとり入れることは我々の研究にとって強力な武 器を得たことになると思われる。

文献

24) 板屋宗明 : 私信

25) 平龙恒: 農化, 35,298 (1961)

26) R. J. Bouthilet, W.Lowrey, J.Assoc.Offic. Agr.Chemists, 42, 634 (1959)

27) 上林 明：ガスクロマトグラフィー第一集, p.193 (1961) 南江堂

29) F. L.Rigby, E.Sihto, A.Bars, J.Inst. Brewing, 66, 242 (1960)

30) G.A.Howard, A.R. Tatchell, ibid. 62,20 (1956)

28) F.C. Rigby, J.L. Bethune, ibid, 63, 154 (1957)

31) A.P. van der Kloot et.al., Proc. A.M.Am. Sco. Brew. Chem. 96 (1958)

32) V.S. Bavisotto, L.A. Roch, ibid, 63 (1959)

33) F.V.Harold et.al., J.Inst. Brewing, 67, 161 (1961)

34) F.V.Harold et.al., ibid, 66, 395 (1960)

35) J. R. Hudson, R. Stevens, ibid, 66, 471 (1960)

36) F.Zientara, J.L.Owades, Am. Brewer, 93, 37 (1960)

37）吉沢 椒：ガスクロマトグラフィー第二集, p.125 (1961)

38) J.Baraud, L.Genevois, Com p. rend., 247, 2479 (1958)

39) A. Foussin, Rev. fermentations et inds. aliment., 14, 206 (1959)

40) L.Fleischmann, A. Daghetta, Ricerca Sci., 28, 228(1958)

41) R. Mecke, M. de Vries, Z. Anal.Chem., 170, 326 (1959)

42) A. Dinsmoor Webb, R.E. Kepner, Am. J. Enolngy. Viticulture. 12, 51 (1961) 